\title{
Effect of Biofertilizer on Growth, Yield and Bioactive Component of Plumbago zeylanica (Lead Wort)
}

\author{
Hetal D. Patel ${ }^{1,2}$, Ramar Krishnamurthy ${ }^{1} \&$ Musibau A. Azeez ${ }^{3}$ \\ ${ }^{1}$ C. G. Bhakta Institute of Biotechnology, Uka-Tarsadia University, Bardoli, Surat, Gujarat, India \\ ${ }^{2}$ 12-Tamari Court, Randolph, New Jersey, USA \\ ${ }^{3}$ Department of Pure and Applied Biology, Ladoke Akintola University of Technology, Ogbomosa, Nigeria \\ Correspondence: Hetal D. Patel, 12-Tamari Court, Randolph-07869, New Jersey, USA. Tel: 1-723-809-0251. \\ E-mail: hetal_pate11603@yahoo.in
}

Received: February 16, 2016

Accepted: March 24, 2016 Online Published: April 15, 2016

doi:10.5539/jas.v8n5p141

URL: http://dx.doi.org/10.5539/jas.v8n5p141

\begin{abstract}
A comparative study on effect of chemical fertilizer and biofertiliser on Plumbago zeylanica for growth, yield and bioactive component was conducted at Bardoli (district-Surat), India between 2012 and 2013 using Random Block Design method and monthly observation of growth parameters. Application of biofertiliser Azotobacter, Azospirillum, Phosphate solubilizing Bacteria and mixture of Aza + Azo + PSB increased plant height, number of branches, number of leaves, length of root, fresh weight, dry weight and bioactive component (plumbagin). Highest effect on height $(91.33 \pm 10.13)$ of plant was obtained with PSB applied biofertiliser whereas the number

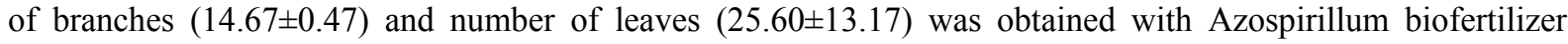
application. The length PSB (33.33 \pm 1.32$)$, fresh weight (26.44 \pm 1.32$)$ and dry weight of roots $(24.66 \pm 1.13)$ was realized with application of mixture of Aza + Azo + PSB. The bioactive component (plumbagin) was high with application of Azospirillum $(0.026 \% \mathrm{w} / \mathrm{w})$ using HPLC. The results of this study suggest that biofertiliser have the potential to increase the growth, yield and bioactive component of Plumbago zeylanica.
\end{abstract}

Keywords: Plumbago zeylanica, biofertiliser, azatobacter, Azospirillum, PSB, HPLC, plumbagin

\section{Introduction}

India with its diverse ecological conditions accounts for 45,000 plant species out of which more than 8,000 species are used in some 10,000 herbal drug formulations. India contributes only a $2.5 \%$ share of the global plant-based drug trade. The demand is increasing fast and supply is putting unreasonable pressure on our wild phyto-resources (Naresh, 1999). Presently, organically produced raw materials of Medicinal and Aromatic plants are more prepared over that of herbs produced by synthetic chemical fertilizer application in the International Market. In agriculture, application of chemical fertilizers is always beneficial to the farmers due to easy availability, application and higher returns in terms of yield, but it is only short-term gain. Biofertiliser application are presently not able to replace, completely, chemical fertilizer but can be used to reduce substantially the high does synthetic fertilizer applications.

One of the highly useful plants in the indigenous systems of medicine is Plumbago zeylanica commonly known as Ceylon, Lead wort, Chitra, Chitrak and Chitramoolan belonging to Plumbaginaceae family and one of the common plants used in Indian traditional system of medicine. A native of South Asia, the species is distributed throughout most of the tropics and subtropics; growing in deciduous woodland, savannas and scrub lands from sea level upto $2000 \mathrm{~m}$ altitude (Paras et al., 2014). The root is used as laxative, expectorant, astringent, abortifacient and in dysentery. Tinchure of root bark is used as antiperiodic. The leaves are caustic and used in treatment of scabies. Plumbagos are chemically characterized by the presence of napthoquinones, flavonoids, terpenoids and steroids, many of them being responsible for several biodynamic activities (Paras et al., 2014). $P$. zeylanica root is powerfully poisonous and its internal use is attended with great danger, it causes abortion. The root is sometimes given internally but more commonly employed as local irritant to the uteri (Sweta et al., 2015).

By understanding importance of medicinal plants and organic farming, the present research was developed to investigate the feasibility of introducing plant as a regular other commercial crops with biofertiliser application under South Gujarat condition in India. It is aimed to study the yield and quality parameter of P. zeylanica, 
whose official commercial plant part is root.

\section{Materials and Methods}

The geographical location of the Experimental field of Uka Tarsadia University, Bardoli Taluka, District-Surat, Gujarat State, India is at $21^{\circ} 7^{\prime} \mathrm{N}$ and $73^{\circ} 6^{\prime} \mathrm{E}$. The station is located at an average elevation of 22 meter ( 72 feet) above sea-level.

The climate here is tropical. In winter, there is much less rainfall in Bardoli than in summer. The average temperature in Bardoli is $27.3{ }^{\circ} \mathrm{C}$. Precipitation here averages $1467 \mathrm{~mm}$. The driest month is January, with $0 \mathrm{~mm}$ of rain. With an average of $596 \mathrm{~mm}$, the most precipitation falls in July. May is the warmest month of the year. The temperature in May averages $31.7^{\circ} \mathrm{C}$. January has the lowest average temperature of the year. It is $22.4{ }^{\circ} \mathrm{C}$. There is a difference of $597 \mathrm{~mm}$ of precipitation between the driest and wettest months. During the year, the average temperatures vary by $9.3{ }^{\circ} \mathrm{C}$. The $\mathrm{pH}$ of soil was 8.96 , Electrical conductivity $0.70 \mathrm{mmhos}$, fine sand $14.13 \%$ and coarse sand $7.10 \%$.

\subsection{Seed Collection and Germination of Seeds}

Seeds were sown in the small plastic trays with 32 holes in the Green house of C.G.Bhakta Institute of Biotechnology, Uka Tarsadia University, Bardoli, Surat, Gujarat, INDIA (July, 2012). Seeds were allowed to germinate. At a height of $6.7 \mathrm{~cm}$ each seedling was uprooted (around 200 seedlings) and transplanted in a bottom perforated polythene bags $(10 \mathrm{~cm}$ height, width $5 \mathrm{~cm}$ ) maintained under the same conditions and watered every 24 hours until the seedling attained an average height of $20 \mathrm{~cm}$. The seven days young 90 seedling plants were randomly selected and then transferred to field for the field trial experiments in first week of August, 2012.

\subsection{Random Block Designing Preparation}

The geographical location of the experimental station was $21^{\circ} 7^{\prime} \mathrm{N} \& 73^{\circ} 6^{\prime} \mathrm{E}$. The station is located at an average elevation of 22 meter above sea level. The experiment was carried out for three replications in a simple random block designed (RBD) field. The experiment was divided into three equal size beds (each bed for individual replication) for the prepared plot, the total area of plot was $16.5 \times 2.3$ meters consisting three ridges of $45 \mathrm{~cm}$ apart and every ridge was $2.25 \mathrm{~m}$ long and $0.6 \mathrm{~m}$ width. Every plot contained 6 columns and 3 rows $(6 \times 3)$ that contained 18 beds. Each bed consists of area $2.5 \times 0.6 \mathrm{~m}$. In each bed, five seedlings were planted with spacing of $45 \mathrm{~cm}$ between each plant.

\subsection{Planting}

The seven days young seedling plants were transferred from green house to the experimental field in RBD. Five plants were planted in each bed keeping space of $45 \mathrm{~cm}$ between each plant and space of $60 \mathrm{~cm}$ between two replication plots. A total 90 plants were grown in moisturizer and farm yard manure containing field plot on August 7, 2012 in experimental field.

\subsection{Application of Chemical fertilizer and Biofertiliser}

A total of six applications of fertilizer were taken into consideration for study:

1) Treatment-1: Control (Farm yard manure)- $T_{1}$;

2) Treatment-2: Chemical Fertilizer- $T_{2}$;

3) Treatment-3: Azatobacter Biofertiliser- $\mathrm{T}_{3}$;

4) Treatment-4: Azospirillum Biofertiliser- $\mathrm{T}_{4}$;

5) Treatment-5: Phosphate Solubilising Bacteria(PSB)- $\mathrm{T}_{5}$;

6) Treatment-6: Aza + Azo + PSB Biofertiliser- $T_{6}$.

The application of chemical and biofertiliser was done to soil prior to planting. About 17 gram of urea was applied to chemical fertilizer treatment labeled bed $\left(\mathrm{T}_{2}\right)$ in each of the three replication of Plumbago zeylanica. Similarly 250 grams of Azatobacter, Azospirillum and PSB containing biofertiliser was applied to bed labeled $\mathrm{T}_{3}$, $\mathrm{T}_{4}$ and $\mathrm{T}_{5}$ respectively in three replications of RBD plot. A mixture of 250 grams of mixed biofertiliser (containing 250 grams of Azatobacter, 250 grams of PSB, 250 grams of Azospirillum) was applied to bed labeled T6 in all replications.

As soon as planting was done, irrigation was continued every 10-15 days in monsoon season and weekly in winters and summers. During growth season hand weeding was conducted every 20 days. 


\subsection{Study of Physical Characteristics}

Biometric observation was taken and the arithmetic mean was recorded. The physical characteristics of plants such as height (in $\mathrm{cm}$ ), total number of branches and total number of leaves were observed, measured and recorded every 30 days and data of measurement was collected before harvest of plants. Total nine months data was collected before harvest.

\subsubsection{Plant Height}

The maximum length of the shoot from the soil surface to the tip of the plant was noted in $\mathrm{cm}$.

\subsubsection{Number of Branches}

The total number of branches growing from the soil on the main axis of shoot was noted.

\subsubsection{Number of Leaves}

The total number of matured leaves were counted manually on plant and noted.

Harvest of plant was done in second week of May 2013 (180 days) by uprooting completely and roots were cut and root length (in $\mathrm{cm}$ ) was measured followed by fresh weight (in grams) and dry weight weight (in grams) of roots i.e biomass using a digital balance.

\subsection{Drying Process}

After measuring the fresh weight of roots, the roots were shade-dried on terrace of C.G. Bhakta insititue of Biotechnology, Uka Tarsadia University, Bardoli, Surat, Gujarat, India for 10 days in month of May-2013 (average temperature $42{ }^{\circ} \mathrm{C}$ ).

\subsection{Grinding Process}

The dried biomass of Plumbago zeylanica, were dried in an oven at $55{ }^{\circ} \mathrm{C}$, then grinded in a mixture and fine ground powder of roots was prepared using $0.5 \mu$ pore size sieve. The prepared powder was packed in an air-tight and moisture free well labeled polythene bags for bioactive component (plumbagin) analysis.

\subsection{Statistical Analysis}

Data collected during the field trial were subjected to statistical analysis (One-way ANNOVA) using SAS software. Duncan's Multiple Range Test (DMRT) at 5\% confidence interval performed differences between the treatments. Correlation between treatments was done by $1 \%$ (two-tailed).

\subsection{Extraction of Bioactive Component}

The extraction of Bioactive component plumbagin from Plumbago zeylanica was performed by Natural Remedies pvt. Ltd., Banglore, Karnataka, India.

\subsection{Standard Preparation for Plumbagin}

$10 \mathrm{mg}$ of Plumbagin (MERCK) was weighed accurately in $50 \mathrm{~mL}$ volumetric flask and dissolved in $20 \mathrm{~mL}$ of HPLC grade methanol by sonication for $5 \mathrm{~min}$. The sample was cooled and volume was made to $100 \mathrm{~mL}$ with methanol.

\subsection{Plumbagin Extraction Procedure}

$1 \mathrm{gm}$ of powder sample of Plumbago zeylanica was weigh accurately and taken in $100 \mathrm{~mL}$ round bottom flask. The powder was dissolved in $20 \mathrm{ml}$ of $50 \% \mathrm{v} / \mathrm{v}$ ethanol by sonicating for $5 \mathrm{~min} .2 \mathrm{~mL}$ of $12 \% \mathrm{w} / \mathrm{v} \mathrm{KOH}$ was added and refluxed on a boiling water bath for 1 hour. After reflection the solution was cooled down and $5.5 \mathrm{~mL}$ of $4 \mathrm{~N} \mathrm{HCL}$ was added and refluxed again on a boiling water bath for 1 hour. Again cooling was done and the $\mathrm{pH}$ was adjusted to $7.5-8.5$ with $12 \% \mathrm{w} / \mathrm{v} \mathrm{KOH}$. After adjusting the $\mathrm{pH}$, the solution was transferred to $100 \mathrm{~mL}$ volumetric flask. The round bottom flask was washed with $50 \% \mathrm{v} / \mathrm{v}$ ethanol to clean the residues and transferred to the same volumetric flask and volume was made to $50 \mathrm{~mL}$ with $50 \% \mathrm{v} / \mathrm{v}$ ethanol. The content was filtered through whatsman filter paper and subjected to HPLC analysis.

2.12 Estimation of Plumbagin with HPLC

1) Instrument: Swmadzu HPLC, LC 2010CHT with UV detector with class LC solution software.

2) Column: Phenomenex Luna, C18, $5.0 \mu(250 \times 4.5 \mathrm{~mm})$, reverse phase.

3) Detection: UV Detector at $256 \mathrm{~nm}$.

4) Mobile phase: (Solvent-A): Dissolve $0.136 \mathrm{~g}$ of anhydrous potassium dihyrogen orthophosphate (KH2PO4) in $900 \mathrm{ml}$ of HPLC grade water and add $0.5 \mathrm{ml}$ of orthophosphoric acid. Make upto $1000 \mathrm{ml}$ of water, filter through 
$0.45 \mu$ membrane and degas in a sonicator for $3 \mathrm{~min}$.

5) Solvent-B: Methanol.

6) Iso-critic flow: Solvent-A (90): Solvent-B (10).

7) Flow rate: $1.000 \mathrm{ml} / \mathrm{min}$.

8) Standard size injected: $0.02 \mathrm{mg} / \mathrm{ml}$ of methanol.

9) Sample size injected: $25 \mathrm{mg} / \mathrm{ml}$ of methanol.

10) Injection volume: $10 \mu 1$.

\section{Results and Discussion}

\subsection{Analysis of Variance (ANNOVA)}

The growth parameters such as plant height, number of branches and number of leaves were significantly affected by different applications of chemical and biofertiliser.

Table 1. Means and standard errors of the vegetative characters of Plumbago zeylanica at six levels of treatments over a period of nine months after planting

\begin{tabular}{|c|c|c|c|c|c|c|c|}
\hline Month & Characters & $\mathrm{T}_{1}$ & $\mathrm{~T}_{2}$ & $\mathrm{~T}_{3}$ & $\mathrm{~T}_{4}$ & $\mathrm{~T}_{5}$ & $\mathrm{~T}_{6}$ \\
\hline \multirow[t]{3}{*}{$1^{\text {st }}$} & Plant Height $(\mathrm{cm})$ & $15.87 \pm 0.47 \mathrm{a}$ & $19.00 \pm 1.45 \mathrm{a}$ & $17.00 \pm 2.42 \mathrm{a}$ & $18.07 \pm 2.21 \mathrm{a}$ & $16.80 \pm 1.97 \mathrm{a}$ & $20.07 \pm 0.57 \mathrm{a}$ \\
\hline & No. of Branches & $1.47 \pm 0.07 \mathrm{a}$ & $1.33 \pm 0.18 \mathrm{a}$ & $1.27 \pm 0.07 \mathrm{a}$ & $1.40 \pm 0.20 \mathrm{a}$ & $1.33 \pm 0.18 \mathrm{a}$ & $1.20 \pm 0.12 \mathrm{a}$ \\
\hline & No. of Leaves & $7.67 \pm 0.27 \mathrm{a}$ & $8.13 \pm 0.79 a$ & $7.60 \pm 0.80 \mathrm{a}$ & $8.80 \pm 0.42 \mathrm{a}$ & $7.60 \pm 0.23 \mathrm{a}$ & $8.93 \pm 0.47 \mathrm{a}$ \\
\hline \multirow[t]{3}{*}{ 2nd } & Plant Height $(\mathrm{cm})$ & $15.93 \pm 2.20 \mathrm{a}$ & $19.73 \pm 2.15 \mathrm{a}$ & $17.80 \pm 2.81 \mathrm{a}$ & $22.53 \pm 2.57 \mathrm{a}$ & $17.40 \pm 2.55 \mathrm{a}$ & $21.20 \pm 2.82 \mathrm{a}$ \\
\hline & No. of Branches & $2.60 \pm 0.42 \mathrm{a}$ & $2.67 \pm 0.29 \mathrm{a}$ & $2.80 \pm 0.31 \mathrm{a}$ & $2.53 \pm 0.07 \mathrm{a}$ & $2.13 \pm 0.18 \mathrm{a}$ & $2.13 \pm 0.07 \mathrm{a}$ \\
\hline & No. of Leaves & $12.73 \pm 0.52 \mathrm{a}$ & $16,53 \pm 2.72 \mathrm{a}$ & $13.07 \pm 1.54 \mathrm{a}$ & $16.13 \pm 2.13 \mathrm{a}$ & $11.47 \pm 0.93 \mathrm{a}$ & $12.53 \pm 1.19 \mathrm{a}$ \\
\hline \multirow[t]{3}{*}{$3^{\text {rd }}$} & Plant Height $(\mathrm{cm})$ & $21.53 \pm 2.26 \mathrm{a}$ & $25.67 \pm 2.25 \mathrm{a}$ & $22.40 \pm 3.35 \mathrm{a}$ & $20.80 \pm 1.60 \mathrm{a}$ & $22.93 \pm 0.59 \mathrm{a}$ & $23.13 \pm 2.66 \mathrm{a}$ \\
\hline & No. of Branches & $2.93 \pm 0.29 \mathrm{a}$ & $3.73 \pm 0.55 \mathrm{a}$ & $3.40 \pm 0.60 \mathrm{a}$ & $3.87 \pm 0.77 \mathrm{a}$ & $3.33 \pm 0.24 \mathrm{a}$ & $3.40 \pm 0.20 \mathrm{a}$ \\
\hline & No. of Leaves & $17.20 \pm 2.03 \mathrm{a}$ & $24.07 \pm 1.30 \mathrm{a}$ & $20.40 \pm 4.71 \mathrm{a}$ & $21.40 \pm 2.50 \mathrm{a}$ & $22.00 \pm 1.86 \mathrm{a}$ & $20.13 \pm 2.57 \mathrm{a}$ \\
\hline \multirow[t]{3}{*}{$4^{\text {th }}$} & Plant Height $(\mathrm{cm})$ & $28.13 \pm 3.86 a$ & $32.07 \pm 1.90 \mathrm{a}$ & $28.07 \pm 3.35 \mathrm{a}$ & $34.60 \pm 4.43 \mathrm{a}$ & $28.13 \pm 5.12 \mathrm{a}$ & $30.67 \pm 1.47 \mathrm{a}$ \\
\hline & No. of Branches & $7.20 \pm 0.99 \mathrm{a}$ & $6.33 \pm 0.52 \mathrm{a}$ & $5.93 \pm 1.20 \mathrm{a}$ & $6.80 \pm 0.95 \mathrm{a}$ & $5.53 \pm 0.44 \mathrm{a}$ & $7.13 \pm 0.27 \mathrm{a}$ \\
\hline & No. of Leaves & $41.67 \pm 2.98 \mathrm{a}$ & $49.80 \pm 2.46 \mathrm{a}$ & $40.27 \pm 8.81 \mathrm{a}$ & $54.93 \pm 9.64 \mathrm{a}$ & $45.87 \pm 7.81 \mathrm{a}$ & $46.13 \pm 4.89 \mathrm{a}$ \\
\hline \multirow[t]{3}{*}{$5^{\text {th }}$} & Plant Height $(\mathrm{cm})$ & $43.60 \pm 5.08 \mathrm{a}$ & $46.80 \pm 0.76 \mathrm{a}$ & $44.73 \pm 5.96 \mathrm{a}$ & $50.73 \pm 5.29 \mathrm{a}$ & $50.20 \pm 6.72 \mathrm{a}$ & $53.93 \pm 1.97 \mathrm{a}$ \\
\hline & No. of Branches & $7.47 \pm 0.53 \mathrm{a}$ & $7.67 \pm 0.52 \mathrm{a}$ & $6.13 \pm 1.87 \mathrm{a}$ & $7.80 \pm 1.01 \mathrm{a}$ & $6.87 \pm 0.77 \mathrm{a}$ & $7.53 \pm 0.47 \mathrm{a}$ \\
\hline & No. of Leaves & $72.0 \pm 17.57 \mathrm{~b}$ & $107.73 \pm 6.27 \mathrm{ab}$ & $73.40 \pm 11.16 \mathrm{~b}$ & $113.60 \pm 4.74 \mathrm{a}$ & $78.53 \pm 14.44 \mathrm{ab}$ & $99.27 \pm 6.97 \mathrm{ab}$ \\
\hline \multirow[t]{3}{*}{$6^{\text {th }}$} & Plant Height $(\mathrm{cm})$ & $71.20 \pm 7.49 \mathrm{a}$ & $71.73 \pm 8.23 \mathrm{a}$ & $62.47 \pm 8.68 \mathrm{a}$ & $75.60 \pm 9.60 \mathrm{a}$ & $76.93 \pm 3.78 \mathrm{a}$ & $71.47 \pm 2.43 \mathrm{a}$ \\
\hline & No. of Branches & $8.73 \pm 0.24 \mathrm{a}$ & $9.60 \pm 1.40 \mathrm{a}$ & $7.93 \pm 1.95 \mathrm{a}$ & $10.07 \pm 1.18 \mathrm{a}$ & $9.87 \pm 1.58 \mathrm{a}$ & $9.07 \pm 0.87 \mathrm{a}$ \\
\hline & No. of Leaves & $86.13 \pm 14.97 \mathrm{c}$ & $121.40 \pm 3.70 \mathrm{ab}$ & $93.00 \pm 10.68 b c$ & $139.47 \pm 6.33 \mathrm{a}$ & $99.20 \pm 8.11 b c$ & $120.33 \pm 6.42 \mathrm{ab}$ \\
\hline \multirow[t]{3}{*}{$7^{\text {th }}$} & Plant Height $(\mathrm{cm})$ & $77.53 \pm 5.67 \mathrm{a}$ & $74.93 \pm 9.74 \mathrm{a}$ & $68.60 \pm 10.40 \mathrm{a}$ & $77.47 \pm 8.21 \mathrm{a}$ & $81.07 \pm 5.33 \mathrm{a}$ & $78.20 \pm 4.35 \mathrm{a}$ \\
\hline & No. of Branches & $8.80 \pm 0.20 \mathrm{a}$ & $9.80 \pm 1.20 \mathrm{a}$ & $8.80 \pm 1.50 \mathrm{a}$ & $10.67 \pm 0.93 \mathrm{a}$ & $10.33 \pm 1.35 \mathrm{a}$ & $9.73 \pm 0.27 \mathrm{a}$ \\
\hline & No. of Leaves & $105.40 \pm 14.43 \mathrm{c}$ & $148.20 \pm 7.79 \mathrm{ab}$ & $124.47 \pm 15.55 \mathrm{bc}$ & $172.13 \pm 8.68 \mathrm{a}$ & $127.20 \pm 11.00 \mathrm{bc}$ & $151.13 \pm 5.98 \mathrm{ab}$ \\
\hline \multirow[t]{3}{*}{$8^{\text {th }}$} & Plant Height $(\mathrm{cm})$ & $90.47 \pm 9.13 \mathrm{a}$ & $77.73 \pm 8.51 \mathrm{a}$ & $68.67 \pm 9.21 \mathrm{a}$ & $80.07 \pm 7.14 \mathrm{a}$ & $87.00 \pm 7.60 \mathrm{a}$ & $80.47 \pm 13.53 \mathrm{a}$ \\
\hline & No. of Branches & $9.87 \pm 0.64 \mathrm{a}$ & $10.67 \pm 1.53 \mathrm{a}$ & $9.33 \pm 0.71 \mathrm{a}$ & $11.33 \pm 0.59 \mathrm{a}$ & $10.73 \pm 0.55 \mathrm{a}$ & $10.13 \pm 1.79 \mathrm{a}$ \\
\hline & No. of Leaves & $130.53 \pm 19.93 \mathrm{c}$ & $176.93 \pm 10.77 \mathrm{ab}$ & $155.13 \pm 18.88 \mathrm{bc}$ & $207.07 \pm 8.66 \mathrm{a}$ & $159.47 \pm 14.20 \mathrm{bc}$ & $184.60 \pm 0.81 \mathrm{ab}$ \\
\hline \multirow[t]{3}{*}{$9^{\text {th }}$} & Plant Height & $90.33 \pm 11.55 \mathrm{a}$ & $82.87 \pm 11.90 \mathrm{a}$ & $80.73 \pm 10.82 \mathrm{a}$ & $90.73 \pm 9.01 \mathrm{a}$ & $91.33 \pm 10.13 \mathrm{a}$ & $86.20 \pm 12.90 \mathrm{a}$ \\
\hline & No. of Branches & $11.80 \pm 0.72 \mathrm{a}$ & $13.00 \pm 1.51 \mathrm{a}$ & $11.87 \pm 0.79 \mathrm{a}$ & $14.67 \pm 0.47 \mathrm{a}$ & $13.33 \pm 0.24 \mathrm{a}$ & $12.33 \pm 1.14 \mathrm{a}$ \\
\hline & No. of Leaves & $149.47 \pm 18.35 c$ & $209.87 \pm 1.65 \mathrm{ab}$ & $186.20 \pm 20.54 b c$ & $250.60 \pm 13.17 \mathrm{a}$ & $185.60 \pm 9.64 b c$ & $209.33 \pm 2.40 \mathrm{ab}$ \\
\hline
\end{tabular}

Note. Means on the same row followed by different letters are significantly different at 0.05 probability level according to Duncan Multiple Range test. 


\subsection{Plant Height}

The effect of all treatments on plant height was significant (Table 1). PSB treatment has the highest $(91.33 \mathrm{~cm})$ plant height while chemical fertilizer application had the least plant height $(82.87 \mathrm{~cm})$ at $9^{\text {th }}$ month compared to control plant. PSB applied plant showed $1 \%$ increase in height whereas chemical fertilizer, Azotobacter, Azospirillum \& Aza + Azo + PSB applied biofertiliser plant showed 10\%, 13\%, 0.6\% and 5\% respectively reduction in plant height. PSB applied biofertiliser showed $78.4 \%$ increase in plant height at $5^{\text {th }}$ month (Table 1) while least growth in height was by $3.5 \%$ in $2^{\text {nd }}$ month.

\subsection{Number of Branches}

The effect of all treatments on number of branches was significant (Table 1). Azospirillum biofertiliser application was highest (14.67) and control plant had the least number of branches (11.80) at $9^{\text {th }}$ month compared to Treatment-1. Azospiriilum applied plant showed 24\% increase whereas in comparison to chemical fertilizer, Azotobacter. PSB \& Aza + Azo + PSB biofertiliser there was 12.8\%, 23\%, 10\% and 18.9\% respectively increase in number of branches. Azospirillum applied biofertiliser showed $80.7 \%$ increase in number of branches at $2^{\text {nd }}$ month and least at $3^{\text {rd }}$ month (1.5\%) (Table 1$)$.

\subsection{Number of Leaves}

The effect of all treatments on number of leaves was significant upto $4^{\text {th }}$ month and non-significant from $5^{\text {th }}$ to $9^{\text {th }}$ month (Table 1). Azospirillum biofertiliser application was highest (250) and control plant had least number of leaves (149.47) at $9^{\text {th }}$ month. Compare to control plant, Azospirillum biofertiliser application showed 67.6\% more leaves number where as Azotobacter, PSB \& Aza + Azo + PSB biofertiliser showed 19\%, 34.5\%, 35\% and $19.7 \%$ respectively increase in number of leaves. Azospirillum biofertiliser application had $54.5 \%$ more leaves at $2^{\text {nd }}$ month of growth.

Table 2. Co-efficient correlations among the vegetative parameters measured during first month in Plumabgo zeylanica treated with different biofertiliser

\begin{tabular}{lllll}
\hline & & Height at 1st month & No. of Branches at 1st month & No. of leaves at 1st month \\
\hline Height at 1st month & Pearson Correlation & 1 & -.025 & $.737^{* *}$ \\
& Sig. (2-tailed) & & .921 & .000 \\
& $\mathrm{~N}$ & 18 & 18 & 18 \\
\hline No. of Branches at 1st month & Pearson Correlation & -.025 & 1 & .271 \\
& Sig. (2-tailed) & .921 & 18 & 18 \\
& $\mathrm{~N}$ & 18 & .271 & 1 \\
\hline No. of leaves at 1st month & Pearson Correlation & $.737^{* *}$ & .276 & 18 \\
& Sig. (2-tailed) & .000 & 18 & \\
\hline
\end{tabular}

Note. ${ }^{* *}$ : Correlation is significant at the 0.01 level (2-tailed).

Table 3. Co-efficient correlations among the vegetative parameters measured during second month in Plumabgo zeylanica treated with different biofertiliser

\begin{tabular}{lllll}
\hline & & Height at 2nd month & No. of Branches at 2nd month & No. of leaves at 2nd month \\
\hline Height at 2nd month & Pearson Correlation & 1 & .053 & $.652^{* *}$ \\
& Sig. (2-tailed) & & .836 & .003 \\
& $\mathrm{~N}$ & 18 & 18 & 18 \\
\hline No. of Branches at 2nd month & Pearson Correlation & .053 & 1 & .043 \\
& Sig. (2-tailed) & .836 & 18 & 18 \\
& $\mathrm{~N}$ & 18 & $.483^{*}$ & 1 \\
No. of leaves at 2nd month & Pearson Correlation & $.652^{* *}$ & .043 & 18 \\
\hline & Sig. (2-tailed) & .003 & 18 & \\
\hline
\end{tabular}

Note. ${ }^{* *}$ : Correlation is significant at the 0.01 level (2-tailed). 
Table 4. Co-efficient correlations among the vegetative parameter measured during third month in Plumabgo zeylanica treated with different biofertiliser

\begin{tabular}{lllll}
\hline & & Height at 3rd month & No. of Branches at 3rd month & No. of leaves at 3rd month \\
\hline Height at 3rd month & Pearson Correlation & 1 & .361 & $.745^{* *}$ \\
& Sig. (2-tailed) & & .142 & .000 \\
& $\mathrm{~N}$ & 18 & 18 & 18 \\
\hline No. of Branches at 3rd month & Pearson Correlation & .361 & 1 & .004 \\
& Sig. (2-tailed) & .142 & 18 & 18 \\
& $\mathrm{~N}$ & 18 & $.643^{* *}$ & 1 \\
No. of leaves at 3rd month & Pearson Correlation & $.745^{* *}$ & .004 & 18 \\
& Sig. (2-tailed) & .000 & 18 & \\
& $\mathrm{~N}$ & 18 &
\end{tabular}

Note. **: Correlation is significant at the 0.01 level (2-tailed).

Table 5. Co-efficient correlations among the vegetative parameters measured during fourth month in Plumabgo zeylanica treated with different biofertiliser

\begin{tabular}{|c|c|c|c|c|}
\hline & & Height at 4 th month & No. of Branches at 4th month & No. of leaves at 4 th month \\
\hline \multirow[t]{3}{*}{ Height at 4 th month } & Pearson Correlation & 1 & .289 & $.859^{* *}$ \\
\hline & Sig. (2-tailed) & & .245 & .000 \\
\hline & $\mathrm{N}$ & 18 & 18 & 18 \\
\hline \multirow[t]{3}{*}{ No. of Branches at 4th month } & Pearson Correlation & .289 & 1 & .389 \\
\hline & Sig. (2-tailed) & .245 & & .110 \\
\hline & $\mathrm{N}$ & 18 & 18 & 18 \\
\hline \multirow[t]{3}{*}{ No. of leaves at 4 th month } & Pearson Correlation & $.859^{* *}$ & .389 & 1 \\
\hline & Sig. (2-tailed) & .000 & .110 & \\
\hline & $\mathrm{N}$ & 18 & 18 & 18 \\
\hline
\end{tabular}

Note. $^{* *}$ : Correlation is significant at the 0.01 level (2-tailed).

Table 6. Co-efficient correlations among the vegetative parameter measured during fifth month in Plumabgo zeylanica treated with different biofertiliser

\begin{tabular}{|c|c|c|c|c|}
\hline & & Height at 5 th month & No. of Branches at 5 th month & No. of leaves at 5 th month \\
\hline \multirow[t]{3}{*}{ Height at 5 th month } & Pearson Correlation & 1 & $.474^{*}$ & $.473^{*}$ \\
\hline & Sig. (2-tailed) & & .047 & .048 \\
\hline & $\mathrm{N}$ & 18 & 18 & 18 \\
\hline \multirow[t]{3}{*}{ No. of Branches at 5th month } & Pearson Correlation & $.474^{*}$ & 1 & $.581^{*}$ \\
\hline & Sig. (2-tailed) & .047 & & .011 \\
\hline & $\mathrm{N}$ & 18 & 18 & 18 \\
\hline \multirow[t]{3}{*}{ No. of leaves at 5 th month } & Pearson Correlation & $473^{*}$ & $.581^{*}$ & 1 \\
\hline & Sig. (2-tailed) & .048 & .011 & \\
\hline & $\mathrm{N}$ & 18 & 18 & 18 \\
\hline
\end{tabular}

Note. *: Correlation is significant at the 0.05 level (2-tailed). 
Table 7. Co-efficient correlations among the vegetative parameter measured during sixth month in Plumabgo zeylanica treated with different biofertiliser

\begin{tabular}{lllll}
\hline & & Height at 6th month & No. of Branches at 6th month & No. of leaves at 6th month \\
\hline Height at 6th month & Pearson Correlation & 1 & .427 & .404 \\
& Sig. (2-tailed) & & .078 & .096 \\
& $\mathrm{~N}$ & 18 & 18 & 18 \\
\hline No. of Branches at 6th month & Pearson Correlation & .427 & 1 & .160 \\
& Sig. (2-tailed) & .078 & 18 & 18 \\
& $\mathrm{~N}$ & 18 & .346 & 1 \\
No. of leaves at 6th month & Pearson Correlation & .404 & .160 & 18 \\
\hline & Sig. (2-tailed) & .096 & 18 & \\
\hline
\end{tabular}

Note. *: Correlation is significant at the 0.05 level (2-tailed).

Table 8. Co-efficient correlations among the vegetative parameters meaured during seventh month in Plumabgo zeylanica treated with different biofertiliser

\begin{tabular}{lllll}
\hline & & Height at 7th month & No. of Branches at 7th month & No. of leaves at 7th month \\
\hline Height at 7th month & Pearson Correlation & 1 & .395 & .309 \\
& Sig. (2-tailed) & & .105 & .212 \\
& $\mathrm{~N}$ & 18 & 18 & 18 \\
& Sig. (2-tailed) & .105 & & .047 \\
& $\mathrm{~N}$ & 18 & 18 & 18 \\
No. of leaves at 7th month & Pearson Correlation & .309 & $.473^{*}$ & 1 \\
& Sig. (2-tailed) & .212 & .047 & 18
\end{tabular}

Note. *: Correlation is significant at the 0.05 level (2-tailed).

Table 9. Co-efficient correlations among the vegetative parameter measured during eighth month in Plumabgo zeylanica treated with different biofertiliser

\begin{tabular}{|c|c|c|c|c|}
\hline & & Height at 8th month & No. of Branches at 8th month & No. of leaves at 8 th month \\
\hline \multirow[t]{3}{*}{ Height at 8 th month } & Pearson Correlation & 1 & $.531^{*}$ & -.034 \\
\hline & Sig. (2-tailed) & & .023 & .893 \\
\hline & $\mathrm{N}$ & 18 & 18 & 18 \\
\hline \multirow[t]{3}{*}{ No. of Branches at 8th month } & Pearson Correlation & $.531^{*}$ & 1 & .011 \\
\hline & Sig. (2-tailed) & .023 & & .965 \\
\hline & $\mathrm{N}$ & 18 & 18 & 18 \\
\hline \multirow[t]{3}{*}{ No. of leaves at 8th month } & Pearson Correlation & -.034 & .011 & 1 \\
\hline & Sig. (2-tailed) & .893 & .965 & \\
\hline & $\mathrm{N}$ & 18 & 18 & 18 \\
\hline
\end{tabular}

Note. *: Correlation is significant at the 0.05 level (2-tailed). 
Table 10. Showing co-efficient correlations among the vegetative character during ninth month in Plumabgo zeylanica treated with different biofertiliser

\begin{tabular}{lllll}
\hline & & Height at 9th month & No. of Branches at 9th month & No. of leaves at 9th month \\
\hline Height at 9th month & Pearson Correlation & 1 & .378 & .176 \\
& Sig. (2-tailed) & & .122 & .484 \\
& $\mathrm{~N}$ & 18 & 18 & 18 \\
\hline No. of Branches at 9th month & Pearson Correlation & .378 & 1 & .076 \\
& Sig. (2-tailed) & .122 & 18 \\
\hline & $\mathrm{N}$ & 18 & .428 & 1 \\
\hline No. of leaves at 9th month & Pearson Correlation & .176 & .076 & 18 \\
\hline & Sig. (2-tailed) & .484 & 18 & 18 \\
\hline
\end{tabular}

Note. *: Correlation is significant at the 0.05 level (2-tailed).

The coefficient correlation among the vegetative character in Plumbago zeylanica applied with different biofertiliser is shown in (Table 2) for $1^{\text {st }}$ month, (Table 3) for $2^{\text {nd }}$ month, (Table 4) for $3^{\text {rd }}$ month, (Table 5) for $4^{\text {th }}$ month, (Table 6) for $5^{\text {th }}$ month, (Table-7) for $6^{\text {th }}$ month, (Table 8) for $7^{\text {th }}$ month, (Table 9) for $8^{\text {th }}$ month, (Table 10) for $9^{\text {th }}$ month. For first four months coefficient correlations is significant at 0.01 level with plant height and number of leaves (Tables 2, 3, 4 and 5). At $5^{\text {th }}$ month, (Table 6) coefficient correlation is significant at 0.01 level with plant height, number of branches $\&$ number of leaves. Co-efficient correlation is non-significant at $6^{\text {th }}, 7^{\text {th }}$ and $9^{\text {th }}$ month (Tables 7, 8, and 10) while $8^{\text {th }}$ month (Table 9) coefficient correlation is significant at 0.05 level with number of branches and number of leaves.

Table 11. Effect of biofertiliser on the growth parameters of Plumbago zeylanica during one season (2012)

\begin{tabular}{llll}
\hline Treatment & Root length in $\mathrm{cm}$ & Fresh weight in gm & Dry weight in gm \\
\hline T1 & 28.5 & 19.6 & 18.9 \\
T2 & 25.6 & 17.9 & 17.5 \\
T3 & 30.7 & 20.3 & 19.9 \\
T4 & 26.7 & 17.5 & 17.0 \\
T5 & 24.7 & 21.4 & 20.9 \\
T6 & 33.3 & 26.4 & 24.7 \\
Sum & 169.7 & 123.3 & 118.9 \\
Mean & 28.2 & 20.5 & 19.8 \\
Count & 6 & 6 & 6 \\
SD & 3.3 & 3.2 & 2.8 \\
SE & 1.3 & 1.3 & 1.1 \\
Variance & 10.6 & 10.5 & 7.7 \\
\hline
\end{tabular}

\subsection{Root Length}

In Table 11 the root length measured after harvest of plant was found highest wit Aza + Azo + PSB applied biofertiliser $(33.33 \mathrm{~cm})$ and least with chemical fertilizer application $(25.6 \mathrm{~cm})$ which was $30 \%$ less. Compare to control plant Azotobacter biofertiliser, Aza + Azo + PSB application has shown 7.8\% and 16.9\% increase in root length where as Azospirillum and PSB applied biofertiliser had shown 7.5\% and $12.8 \%$ reduction in root length.

\subsection{Fresh Weight and Dry Weight}

In Table 11 the Fresh and Dry weight were highest with Aza + Azo + PSB applied biofertiliser and least with 
Azospirillum biofertiliser. Compare to control, Azatobacter. PSB \& Aza + Azo + PSb biofertiliser showed 3.5\%. $9 \%$ and $34.8 \%$ respectively more fresh weight and $5 \%, 10.6 \%$ and $30.4 \%$ respectively with dry weight.

According to the present analysis, biofertiliser increased plant height by enhancing the nitrogen content. Results are confirmed by the work carried out on Corriandrum sativum (Akhani et al., 2012). The present result were derived from the improvement of nitrogen fixing bacteria activities in soil, which is in agreement with the previous studies carried out on the fennel, turmer and hyssop (Mahfouz \& Sharaf Eldin, 2007). Biofertilizer has significantly influenced the growth parameters. Increase in growth parameter may be due to biofertiliser application might be due to the vital role of bacteria present in the applied biofertiliser. Similar reports are observed in few medicinal plants reported by Paramanik et al. (2014), Ghilavizadeh et al. (2013), and Tabrizi et al. (2010). On the other hand, biofertiliser through the improvement of biological activities of soil and mineral element absorption caused more biomass production. These findings are in accordance with the observation Mahfouz and Sharaf Eldin (2007). Effect of biofertiliser on the dry weight of plant was due to increased nitrogen uptake and the growth rate improvement. This is reported in work done by Mahfouz and Sharaf Eldin (2007) on fennel crop. Many researchers (AL-Fraihat et al., 2011; Valadabadi \& Farahani, 2011) also report effect of biofertiliser on dry weight. Moreover, the increase in fresh weight could be explained by increasing metabolic activities of the plant under the effect of biofertiliser that gave significant values for fresh weight. Researchers (Al-Fraihat et al., 2011) report similar reports. There are reports of PSB as a single biofertiliser significantly increased the biomass yield in Stevia rebaudiana (Das et al., 2007; Sial et al., 2015) and similar results are observed in this experimental analysis. PSB biofertiliser did not show significant effect on the plant height and similar results are observed in Pimpinella anisum (Darzi et al., 2012). The root length of Plumbago zeyalnica was significantly influenced by biofertiliser. Such increase in root length and significant influence of biofertiliser is reported in Catharanthus roseus (Lenin et al., 2012). PSB biofertiliser has shown its effect on the increase of plant height in the present study and same is reported in Tagetes erecta (Hashemabadi et al., 2012), in Plantago ovate Forsk (Pouryousef et al., 2007), in Zea mays (Beyranvand et al., 2013). Occurrence of maximum number of branches by Azospirillum is reported in Pomegranate (Anseri et al., 2008. Azospirillum increased the plant height is also reported in Rosmarinus officinalis (Abdullah et al., 2012), in guar plant (Gendy et al., 2013) in Anethum graveolens (Darzi et al., 2012).

Present study reveals the positive effect of biofertiliser on the growth parameters of the medicinal plants.

Table 12. Analysis of Variance (ANOVA) for effects of chemical fertilizer and biofertiliser on the growth parameters (height, branches and leaves) of Plumbago zeylanica

\begin{tabular}{lllllll}
\hline Source of Variation & SS & Df & MS & F & P-value & F crit \\
\hline Between Groups & 19957.46 & 2 & 9978.731 & 140.4334 & $1.94 \mathrm{E}-10$ & 3.68232 \\
Within Groups & 1065.85 & 15 & 71.05666 & & & \\
Total & 21023.31 & 17 & & & \\
\hline
\end{tabular}

In Table 12 Fcritical $<$ F calculate value so we reject null hypothesis that all the means are equal in favor of the alternate hypothesis that at least two of the means are different. Here $p<0.05$ and $p<0.001$ which also reject null hypothesis meaning there is a significant difference between group means. There is significant positive relationship between the treatments and the height, number of branches and number of leaves of the plant.

Table 13. Analysis of Variance (ANOVA) for effects of chemical fertilizer and biofertiliser on the growth parameters (root length, fresh weight and dry weight) of Plumbago zeylanica

\begin{tabular}{lllllll}
\hline Source of Variation & SS & Df & MS & F & P-value & F crit \\
\hline Between Groups & 264.4466 & 2 & 132.2233 & 13.76248 & 0.000404 & 3.68232 \\
Within Groups & 144.1128 & 15 & 9.607522 & & & \\
Total & 408.5595 & 17 & & & \\
\hline
\end{tabular}

In Table 13 Fcritical $<$ Fcalculate value so we reject null hypothesis that all means are equal in favor of the alternate hypothesis that at least two of the means are different. Here $p<0.05$ and $p<0.001$ which also reject 
null hypothesis meaning there is a significant difference between group means. There is significant positive relationship between the treatments and the root length, fresh weight and dry weight.

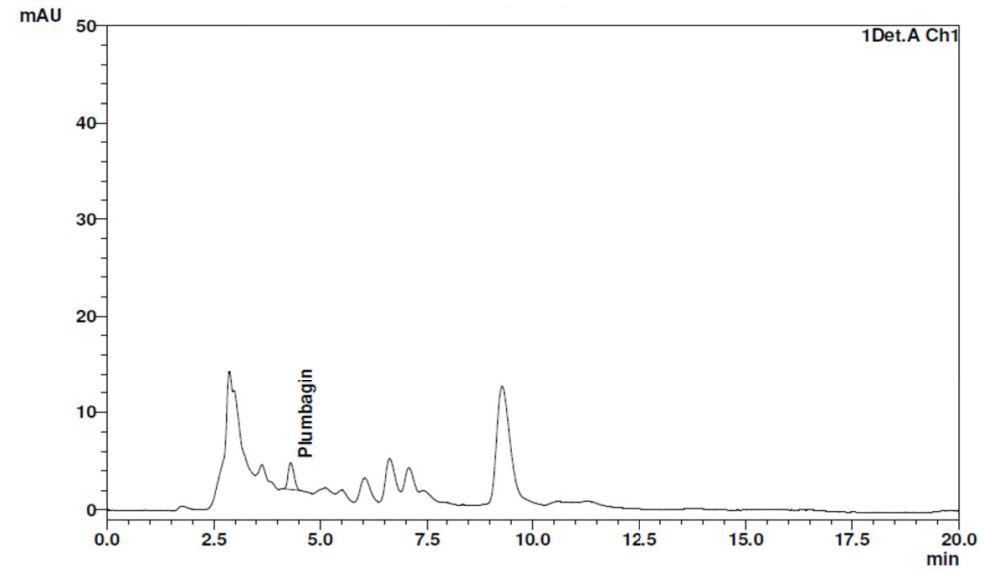

Figure 1. HPLC chromatogram of plumbagin peak for control plant (Treatment-1)

Table 14. Retention time of control plant (Treatment-1) having Detector A Chl $256 \mathrm{~nm}$

\begin{tabular}{lllll}
\hline Peak\# & Retention Time & Name & Area & Area\% \\
\hline 1 & 4.305 & Plumbagin & 25983 & 100.000 \\
Total & & 25983 & 100.000 \\
\hline
\end{tabular}

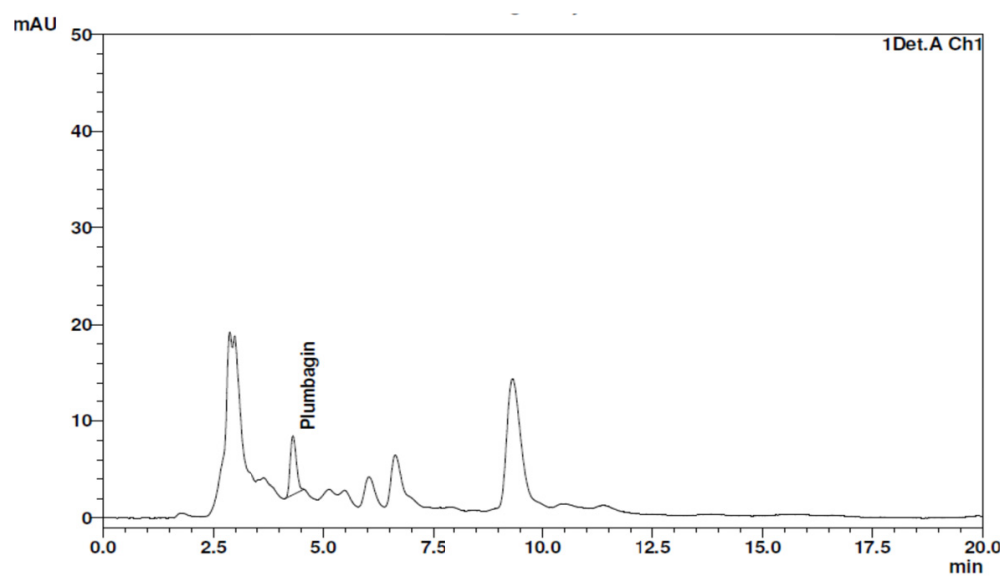

Figure 2. HPLC chromatogram of plumbagin peak for plant having application of chemical fertilizer (Treatment-2)

Table 15. Retention time of plant having application of chemical fertilizer (Treatment-2)

\begin{tabular}{lllll}
\hline Peak\# & Retention Time & Name & Area & Area\% \\
\hline 1 & 4.309 & Plumbagin & 58129 & 100.000 \\
Total & & & 58129 & 100.000 \\
\hline
\end{tabular}




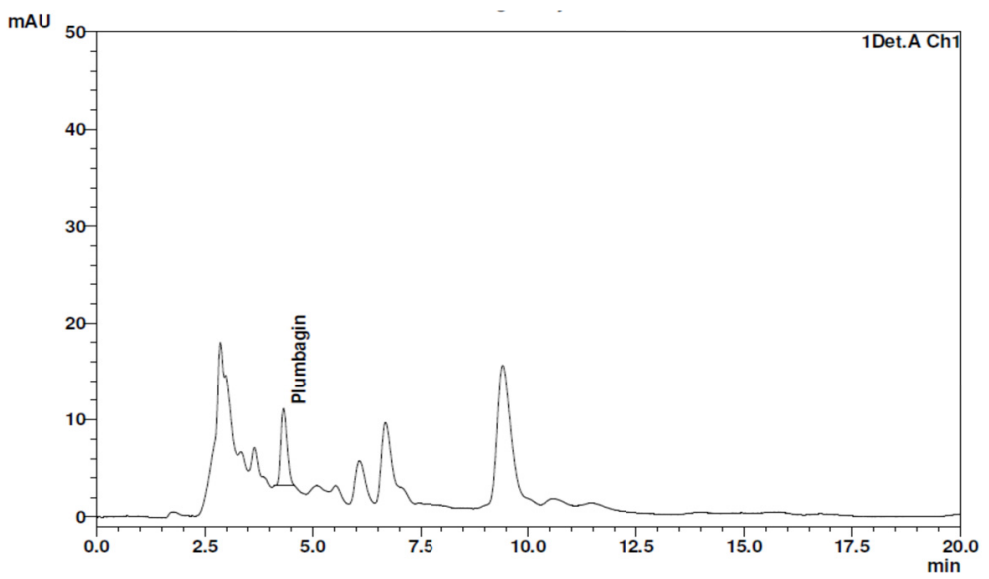

Figure 3. HPLC chromatogram of plumbagin peak for plant having application of azotobacter biofertiliser (Treatment-3)

Table 16. Retention time of plant having application of Azotobacter biofertiliser (Treatment-3) having Detector A Chl $265 \mathrm{~nm}$

\begin{tabular}{|c|c|c|c|c|}
\hline Peak\# & Retention Time & Name & Area & Area $\%$ \\
\hline 1 & 4.321 & Plumbagin & 79639 & 100.000 \\
\hline Total & & & 79639 & 100.000 \\
\hline
\end{tabular}

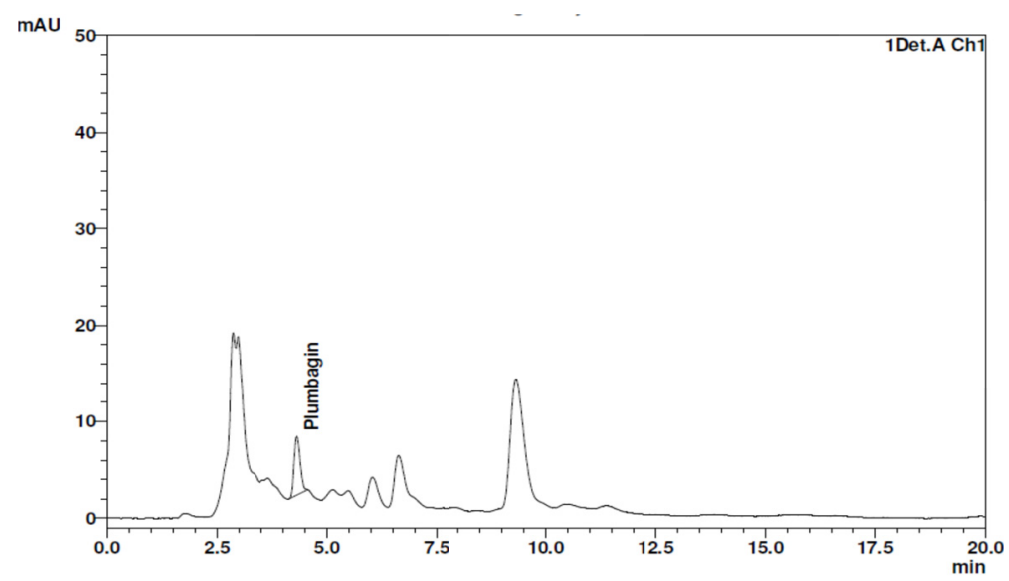

Figure 4. HPLC chromatogram of plumbagin peak for plant having application of azospirillum biofertiliser (Treatment-4)

Table 17. Retention time of plant having application of Azospirillum biofertiliser (Treatment-4) having Detector A Chl $265 \mathrm{~nm}$

\begin{tabular}{lllll}
\hline Peak\# & Retention Time & Name & Area & Area $\%$ \\
\hline 1 & 4.324 & Plumbagin & 266829 & 100.000 \\
Total & & & 266829 & 100.000 \\
\hline
\end{tabular}




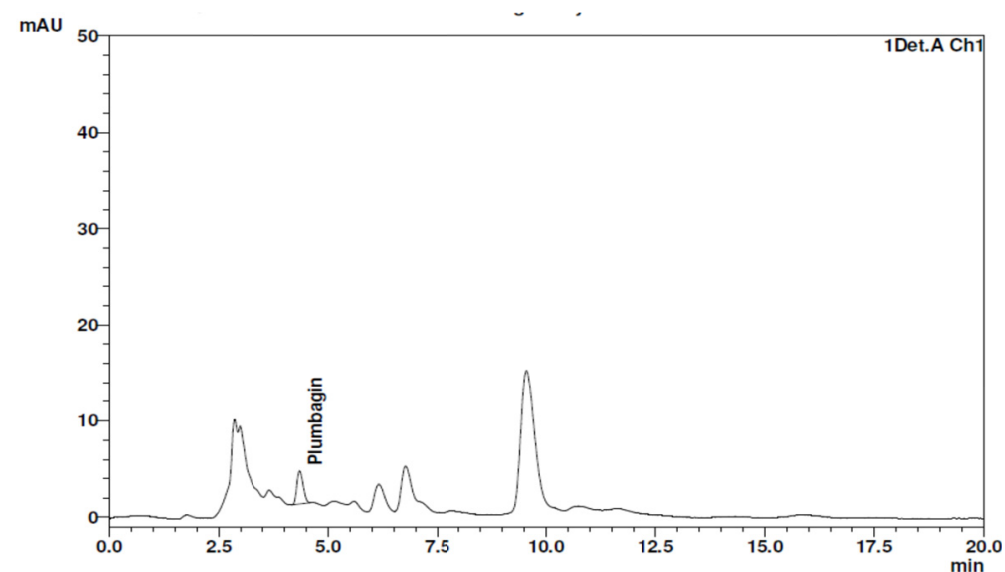

Figure 5. HPLC chromatogram of plumbagin peak for plant having application of phosphate solubilizing bacteria biofertiliser (Treatment-5)

Table 18. Retention time of plant having application of phosphate solubilizing bacteria biofertiliser (Treatment-5) having Detector A Chl $265 \mathrm{~nm}$

\begin{tabular}{lllll}
\hline Peak\# & Retention Time & Name & Area & Area\% \\
\hline 1 & 4.343 & Plumbagin & 33649 & 100.000 \\
Total & & & 33649 & 100.000 \\
\hline
\end{tabular}

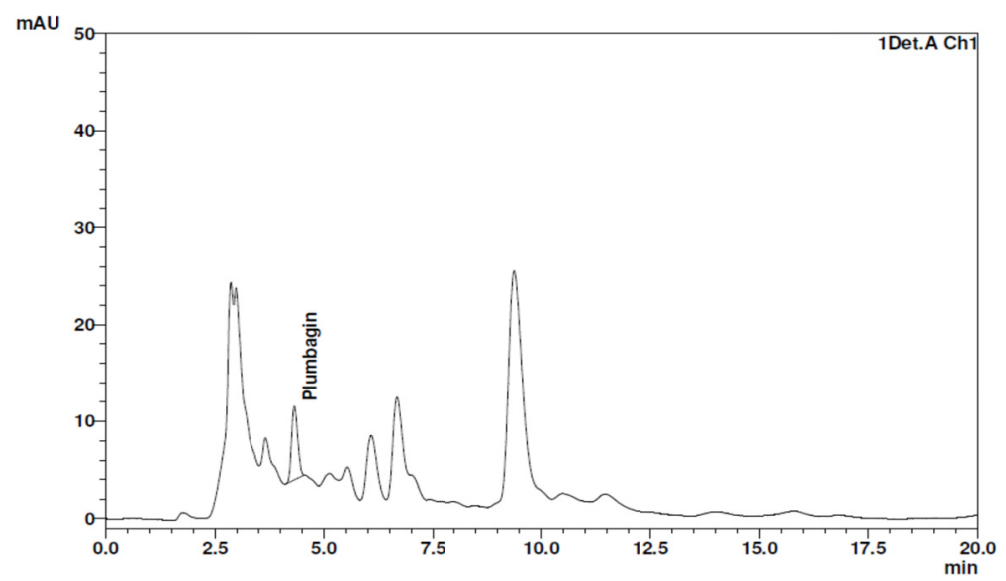

Figure 6. HPLC chromatogram of plumbagin peak for plant having application of Aza + Azo +PSB biofertiliser (Treatment-6)

Table 19. Retention time of plant having application of Aza + Azo + PSB biofertiliser (Treatment-6) having Detector A Chl $265 \mathrm{~nm}$

\begin{tabular}{lllll}
\hline Peak\# & Retention Time & Name & Area & Area\% \\
\hline 1 & 4.316 & Plumbagin & 74640 & 100.000 \\
Total & & & 74640 & 100.000 \\
\hline
\end{tabular}




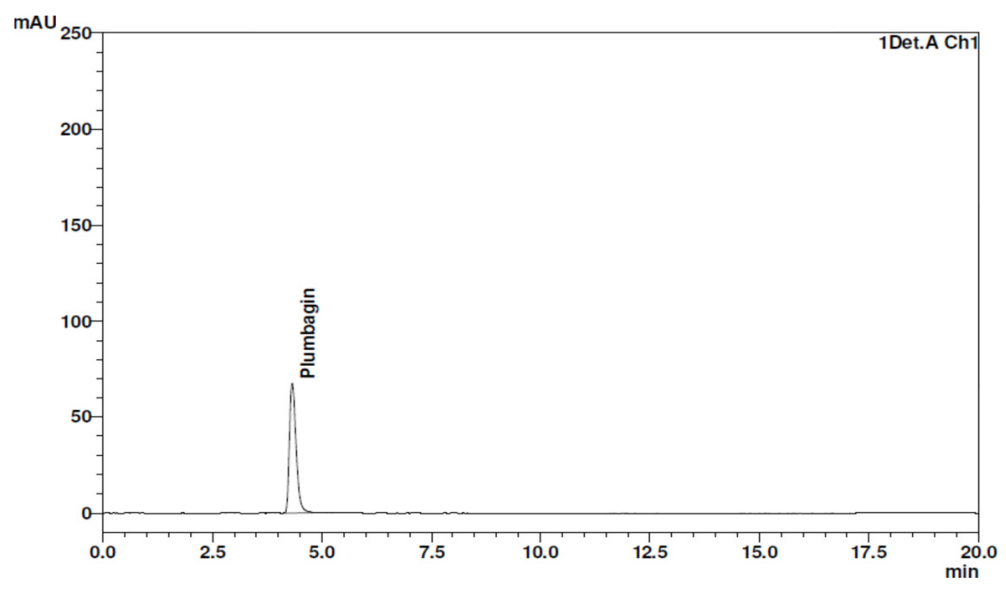

Figure 7. HPLC chromatogram of standard plumbagin peak

Table 20. Retention time of standard plumbagin having Detector A Chl $265 \mathrm{~nm}$

\begin{tabular}{lllll}
\hline Peak\# & Retention Time & Name & Area & Area\% \\
\hline 1 & 4.318 & Plumbagin & 708502 & 100.000 \\
Total & & & 708502 & 100.000 \\
\hline
\end{tabular}

Table 21. Comparison of the concentration of plumbagin content in plumbago zeylanica roots after application of chemical fertilizer and biofertiliser

\begin{tabular}{llll}
\hline Sr. No & Treatment & Description & $\begin{array}{l}\text { Results Plumbagin by HPLC (\%w/w) } \\
\text { "As is" Basis }\end{array}$ \\
\hline 1 & Treatment-1: Control & Brown powder & 0.004 \\
2 & Treatment-2: Chemical fertilizer & Brown powder & 0.006 \\
3 & Treatment-3: Azotobacter & Brown powder & 0.008 \\
4 & Treatment-4: Azospirillum & Brown powder & 0.026 \\
5 & Treatment-5: Phosphate Solubilizing Bacteria & Brown powder & 0.007 \\
6 & Treatment-6: Aza + Azo + PSB & Brown powder & 0.007 \\
\hline
\end{tabular}

\subsection{HPLC for Plumbagin Content}

From Table 21 it is observed that Treatment-4 (Azotobacter biofertiliser) gave the best result in the concentration of Plumbagin $(0.026 \% \mathrm{w} / \mathrm{w})$ while least was observed with Treatment-1 (Control) showed the least concentration of Plumbagin $(0.004 \% \mathrm{w} / \mathrm{w})$. There was not much difference in the concentration of Plumbagin among rest of the treatments.

Using Detector A Chl $256 \mathrm{~nm}$ the retention time of Plumbagin in Control (Table 14), Chemical fertilizer (Table 15), Azotobacter (Table 16), Azospirillum (Table 17), PSB (Table 18) and Aza + Azo + PSB applied (Table 19) biofertiliser root powder extract was 4.305, 4.309, 4.321, 4.324, 4.343 and 4.316 respectively. The retention time of Standard plumbagin is 4.318 (Table 20); the range is 4.305 to 4.343 for the elution of the bioactive compound (plumbagin) from the root of the plant. Similar retention time detection was studied in sample obtained from biofertiliser-applied plant (Roa et al., 2012). Highest retention time is seen in PSB applied biofertiliser root powder extract while least is seen in control. Other constituents present in the extract obtain total one peak of plumbagin in each graph indicating there is no interference in the elution with other constituents and plumbagin content was free from interference. Such results are also reported in quantitative analysis of plumbagin in root extract of Plumbago zeyalnica (Jain et al., 2013). The amount of plumbagin present in extract was determined by comparing the peak area from the standard (Figures 4, 6, and 7). The concentration of Plumbagin was high in Azospirillum applied biofertiliser root powder extract and less in control root powder extract. Compare to control root powder extract there was increase in the content by $33.3 \%, 50 \%, 84.6 \%, 42.8 \%$ and $42.85 \%$ in Chemical fertilizer, Azatobacter, Azospirillum, PSB and Aza + Azo + PSB applied treatments (Table-21) 
concentration in root extracts is found to be $40 \mathrm{mg} / 100 \mathrm{gm}, 60 \mathrm{mg} / 100 \mathrm{mg}, 80 \mathrm{mg} / 100 \mathrm{mg}, 2.6 \mathrm{~g} / 100 \mathrm{gm}, 70$ $\mathrm{mg} / 100 \mathrm{gm}$ and $70 \mathrm{mg} / 100 \mathrm{gm}$ in treatments T1, T2, T3, T4, T5 and T6 respectively. Similar results for determination of plumbagin can be obtained by HPTLC method (Pawar et al., 2010). Results obtained by HPLC method are efficient for qualitative identification and researchers (Muhammad et al, 2009) report quantitative determination of plumbagin. HPLC was performed to determine the purity of bioactive component through extraction and such results are also observed in other works studied (Arunachalam et al., 2010).

\section{Conclusion}

The growth parameters: height of plant, number of branches, and number of leaves, root length, fresh weight and dry weight were found to be improved in the plants, which were given the application of Azospirillum, PSB and Aza + Azo + PSB biofertiliser. The plant applied with Azotobacter biofertiliser did not have impact on growth parameters. Data obtained with Azotobacter biofertiliser were not very encouraging.

The concentration of Plumbagin was found to be highest in the roots of Azospirillum applied biofertiliser and the least concentration was found in control plant. Compare to Azospirillum applied biofertiliser roots; other biofertiliser-applied roots did not enhance the concentration plumbagin during growth and development of plant.

\section{Acknowlegements}

The authors thanks C.G. Bhakta Institute of Biotechnology, Uka Tarsadia University, Bardoli, India to provide experimental field and Natural Remedies Ltd, Banglore, India to conduct HPLC analysis of Plumbagin for this research.

\section{References}

Abdullah, A. T., Hanafy, M. S., Ghawwas, E. O. E. L., \& Ali, Z. H. (2012). Effect of Compost and some bio fertilizers on Growth, Yield, Essential Oil Productivity and Chemical Composition of Rosmarinus officinalis L. Plants. Journal of Horticulatural Science \& Ornamental Plants, 4(2), 201-214. Retrieved from http://www.idosi.org/jhsop/4(2)12/10.pdf

Akhani, A., Darzi, M. T., \& Seyed Hadi, M. H. (2012). Effects of Biofertilizer and Plant Density on Yield Components and Seed Yield of Coriander (Coriandrum Sativum). International Journal of Agriculture and Crop Sciences, 4(16), 1205-1211. Retrieved from http:/ijagcs.com/wp-content/uploads/2012/10/12051211.pdf

Al-Fraihat, A. H., Al-dalain, S. Y. A., Al-Rawashdeh, Z. B., Abu-Darwsih, M. S., \& Al-Tabbal, J. A. (2011). Effect of organic and biofertilizers on growth, herb yield, and volatile oil of marjoram plant grown in Ajloun region, Jordan. Journal of Medicinal Plants Research, 5(13), 2822-2833. Retrieved from http://www.academicjournals.org/app/webroot/article/article1380551873_Al-Fraihat.pdf

Anseri, G. K., Jain, N., Panwar, J., Roa, A. V., \& Meghwal, P. R. (2008). Biofertilizers improve plant growth, fruit yield, nutition, metabolism and rhizosphere enzyme activities of Pomegranate (Punica granatum L.) in Indian Thar Desert. Scientia Horticulturae, 117, 130-135. http://dx.doi.org/10.1016/j.scienta.2008.03.014

Arunachalam, K. D., Velmurugan, P., \& Raja, R. B. (2010). Anti-inflammatory and cytotoxic effects of extract from Plumbago zeylanica. African Journal of Microbial Research, 4(12), 1239-1245. Retrieved from http://www.academicjournals.org/journal/AJMR/article-abstract/634206613560

Beyranvand, H., Farnia, A., Nakhjavan, S., \& Shaban, M. (2013). Response of yield and yield components of maize (Zea mays L.) to different biofertilizers. International journal of Advanced Biological and Biomedical Research, 1(9), 1068-1077. Retrieved from http://ijabbr.com/pdf_7870_6bdafc892c529e640ff42 93403842 eaf.html

Darzi, M. T., Seyedhadi, M. H., \& Rejali, F. (2012). Effects of the application of vermicompost and phosphate solubilizing bacterium on the morphological traits and seed yield of anise (Pimpinella anisum L.). Journal of Medicinal Plants Research, 6(2), 215-219. Retrieved from http://www.academicjournals.org/journal/JMP R/article-full-text-pdf/FABF47017494

Das, K., Dang, R., Shiavananda, T. N., \& Sekeroglu, N. (2007). Influence of bio-fertilizers on the biomass yield and nutrient content in Stevia rebaudana Bert. Grown in Indian subtropics. Journal of Medicinal Plants Research, 1(1), 5-8.

Ghilavizadeh, A., Darzi, M. T., \& Seyed Hadi, M. H. (2013). Effects of biofertilizer and Plant Density on Essential Oil Content and Yielf Traits of Ajowan (Carcum copticum). Middle-East Journal of Scientific Research, 14(11), 1508-1512. Retrieved from http://idosi.org/mejsr/mejsr14(11)13/15.pdf 
Hashemabadi, D., Zaredost, F., Ziyabari, M. B., Zarachini, M., Kaviani, B., Solimandarabi, M. J., ... Zarchini, S. (2012). Influence of phosphate bio-fertilizer on quantity and quality features of marigold (Tagetes erecta L.). Australian Journal of Crop Science, 6(6), 1101-1109.

Jain, A. P., Hamrapurkar, P. D., Labana, S. M., Madrewar, D. M., \& Sonandkar, A. A. (2014). Quantitative Analysis of Plumbagin in Root Extract of P. zeylanica linn Using HPLC. Int. J. Pharma. Sci. Rev. Res., 24(1), 168-171.

Kumar, N., Tasleem, Arif., Bhosale, J. D., Mandal, T. K., Bendre, R. S., Lavekar, G. S., \& Dabur, R. (2009). Natural products-antifungal agents derived from plants. Journal of Asian Natural Products Research, 11(7), 621-638. http://dx.doi.org/10.1080/10286020902942350

Lenin, G., \& Jayanthi, M. (2012). Efficiency of plant growth promoting rhizobacteria (PGPR) on enhancement of growth, yield an dnutrient content of Cantharanthus roseus. Intrnational Journal of Research in Pure and Applied Microbiology, 2(4), 37-42. Retrieved from http://urpjournals.com/tocjnls/44_12v2i4_2.pdf

Mahfouz, S. A., \& Sharaf-Eldin, M. A. (2007). Effect of mineral vs. biofertilizer on growth, yield, and essential oil content of fennel (Foeniuclum vulgare Mill.). Int. Agrophysics, 21, 361-366. Retrieved from https://www.researchgate.net/profile/Mahmoud_SharafEldin2/publication/26551991_Effect_of_mineral_vs. _biofertilizer_on_growth_yield_and_essential_oil_content_of_fennel_(Foeniculum_vulgare_Mill.)/links $/ 55$ a38ddb08aeaefdb97bc554.pdf

Muhammad, H. M., Saour, K. Y., \& Naqishbandi, A. M. (2009). Quantitative and Qualitative Analysis of Plumbagin in the Leaf and Root of Plumbago europaea GrowingNaturally in Kurdistan by HPLC. Iraqu $J$ Pharma Sci., 18(Suppl.). Retrieved from http://copharm.uobaghdad.edu.iq/uploads/journal\%20final/ 18[1]2009supp.pdf\#page $=56$

Paramanik, R. C., \& Chikkaswamy, B. K. (2014). Effects of VAM and Biofertilizers on some medicinal plants. International Journal of Current Microbiology and Applied Sciences, 3(6), 1016-1027.

Paras, J., et al. (2014). Pharmacological Profiles of Ethno-Medicinal Plant: Plumbago zeylanica L. Int. J. Pharm. Sci. Rev. Res., 24(1), 157-163. Retrieved from https://www.researchgate.net/profile/Paras_Jain/public cation/272102490_Pharmacological_Profiles_of_Ethno-Medicinal_Plant_Plumbago_zeylanica_1.-_A_Revi ew/links/54db33810cf233119bc57280.pdf

Pawar, R. K., Sharma, S., Singh, K. C., \& Sharma, R. K. (2010). HPTLC mehod for the determination of Plumbagin zeylanica Linn (root). Int. J. Pharm Pharm Sci., 2, 219-223.

Pouryousef, M., Chaichi, M., Mazaher, D., Fakhretabatabii, M., \& Jafar, A. (2007). Effect of Different Soil Fertilizing Systems on Seed and Mucilage Yield and Seed P Content of Isabgol (Plantago ovate Forsk). Asian Journal of Plant Sciences, 6(7), 1088-1092. http://dx.doi.org/10.3923/ajps.2007.1088.1092

Roa, D., Vijaya, T., Naidu, B., Subramanyam, P., \& Rayalu, D. (2012). Phytochemcial screening and antimicrobial studies of compounds isolated from Plumbago zeylanica L. International Journal of Analytical Pharmaceutical and Biomedical Sciences, 1(3), 82-90.

Sao, S., \& Dubey, S. (2015). Antimicrobial Activity of Leaves Extract of Plumbago zeylanica Plant against Known Drugs. IJRSB, 3(6), 1-6.

Sial, N. A., Memom, M. Y., Abro, S. A., Shah, J. A., Depar, N. D., \& Abbas, M. (2015). Efect of Phosphate solubilizing bacteria (Bacillous megatherium) and Phosphate fertilizer on yield and yield components of Wheat. Pak. J. Biotechnol., 12(1), 35-40.

Tabrizi, L., Koocheki, A., \& Ghobani, R. (2008). Effect of Biofertilizers on Agronomic Criteria of Hyssop (Hyssopus officinalis). $16^{\text {th }}$ IFOAM Organic World Congress Modena, Italy.

Valadabadi, S. A., \& Farahani, H. A. (2011). Investigation of biofertilizers influence on quality and quality characterisitics in Nigella sativa L. Journal of Horticulture and Forestry, 3(3), 88-92. Retrieved from http://www.academicjournals.org/article/article1379499567_Farahani\%20\%20and\%20Valadabadi.pdf

\section{Copyrights}

Copyright for this article is retained by the author(s), with first publication rights granted to the journal.

This is an open-access article distributed under the terms and conditions of the Creative Commons Attribution license (http://creativecommons.org/licenses/by/3.0/). 